УДК 636.4:619:615:619:616.36:619:616.34-002

(C) 2016

Шатохін П. П., кандидат ветеринарних наук,

Кравченко С. О., кандидат ветеринарних наук,

Канівець Н. С., кандидат ветеринарних наук,

Каришева Л. П., старший викладач кафедри терапії

Полтавська державна аграрна академія

\title{
ВПЛИВ АЦЕТИЛСАЛІЦИЛОВОЇ КИСЛОТИ НА СТАН ГЕПАТОЦИТІВ ПОРОСЯТ ЗА ГАСТРОЕНТЕРИТУ
}

\section{Рецензент - доктор ветеринарних наук, професор В. О. Свстаф'єва}

У публікащії наведено дані щзодо впливу ащетилсалічилової кислоти (аспірину) на стан гепатоцитів за лікування поросят, хворих на гастроентерит. Визначено активність аспартат- $i$ аланінамінотрансферази сироватки крові молодняку відлучного віку, які $\epsilon$ інформативними ферментами стосовно обмінних прочесів у печінці, а саме обміну амінокислот. Встановлено, що застосування водорозчинного аспірину тваринам з лікувальною метою не має гепатотоксичної дії, на відміну від асглюколу, у разі застосування якого відбувається руйнування гепатоцитів, щзо підтверджується гіперферментемією АсАT $i$ АлАT.

Ключові слова: поросята, амінотрансферази, гастроентерит, аспірин,сироватка крові.

Постановка проблеми. Свинарство несе в собі низку проблем, серед яких найбільш актуальною $є$ збереження молодняку [5]. Найчастіше причиною захворювань є порушення умов годівлі й утримання, що сприяє виникненню внутрішніх хвороб, серед яких значне місце займає патологія шлунково-кишкового тракту (гастрит, гастроентерит тощо) [7, 11]. Для лікування хворих тварин у наш час застосовують значну кількість імуностимуляторів, протимікробних, симптоматичних та патогенетичних препаратів. Однак за цих захворювань досить незначне місце відводиться нестероїдним протизапальним засобам [9].

Тому аналіз окремих біохімічних показників сироватки крові в процесі лікування поросят, хворих на гастроентерит, нестероїдними протизапальними засобами є своєчасним і актуальним.

Аналіз останніх досліджень і публікацій, у яких започатковано розв'язання проблеми. Аналізуючи дані літературних джерел, слід відмітити, що свині - це продуктивні, швидкоростучі тварини, які схильні, за неправильного утримання і годівлі, до різних захворювань як інфекційної, так і незаразної етіології [5].

У світовій ветеринарній практиці розроблено значну кількість схем лікувань у разі захворювань свиней на гастроентерит із застосуванням різних нестероїдних протизапальних препаратів (саліцилати, похідні пропіонової і оцтової кислот тощо) [9].

Більшість нестероїдних протизапальних препаратів (НПЗП) діють як неселективні інгібітори ферменту циклооксигенази (ЦОГ). ЦОГ каталізує утворення простагландинів і тромбоксану 3 арахідонової кислоти (яка утворюється 3 подвійного шару фосфоліпідів за участі фосфоліпази $\mathrm{A}_{2}$ ). Простагландини діють (поміж іншим) в якості молекул-посередників, також вони потрібні для захисту слизової оболонки шлунка від різних впливів, тому аспірин створює побічну дію у вигляді подразнення стінок шлунка [4].

Оскільки більшість нестероїдних протизапальних препаратів є слабкими кислотами (рН 3-5), то вони добре абсорбуються зі шлунка і слизової оболонки кишечника. Потім у значній мірі зв'язуються з білками плазми (зазвичай > $>5$ \%), як правило, з альбуміном, тому їхній об'єм розподілу звичайно наближається до об'єму плазми. Більшість НПЗП метаболізуються в печінці шляхом окиснення і кон'югації до неактивних метаболітів, які частково виділяються із жовчю [4].

Не секрет, що основна роль печінки в організмі - це обмін речовин. Зважаючи на вищезазначене, рівень метаболічних процесів у печінці можна оцінити за активністю ферментів, зокрема аспартат- (АсАТ) і аланінамінотрансферази (АлАТ), що беруть участь в обміні амінокислот. АсАТ каталізує реакцію трансамінування між аспартатом та $\alpha$-кетоглутаратом, у результаті чого утворюється оксалоацетат та глутамат. АсAТ має цитоплазматичну та мітохондріальну ізоформи. Аланінамінотрансфераза каталізує реакцію трансамінування між аланіном та $\alpha$ кетоглутаратом з утворенням піровиноградної та $\alpha$-глютамінової кислот [3]. Трансамінування становить заключний етап синтезу замінних амінокислот із відповідних $\alpha$-кетокислот, у результаті чого відбувається перерозподіл амінного 


\section{ВЕТЕРИНАРНА МЕДИЦИНА}

азоту в тканинах організму. Водночас трансамінування - перша стадія дезамінування більшості амінокислот, а кетокислоти, які в цьому разі утворюються, окислюються у циклі трикарбонових кислот та використовуються для синтезу глюкози і кетонових тіл [3, 10].

Аналізуючи доступні дослідження і публікації [8], слід зазначити, що застосування водорозчинного аспірину, як нестероїдного протизапального засобу для лікування тварин за гастроентериту та його дії на печінку $є$ маловивченим, а тому, безперечно, актуальним.

Метою досліджень було встановлення активності амінотрансфераз сироватки крові поросят за гастроентериту в процесі лікування нестероїдним протизапальним засобом (водорозчинний аспірин).

Завдання - проаналізувати отримані результати біохімічних досліджень крові.

Матеріали і методи дослідження. Дослідження проводили в умовах приватного господарства та лабораторії кафедри терапії Полтавської державної аграрної академії.

Об'єкт дослідження - поросята відлучного віку, хворі на гастроентерит. Для проведення досліду, за принципом аналогів, було сформовано дві дослідні групи тварин, по сім голів у кожній з ознаками гастроентериту.

Лікування хворих тварин проводили за такою схемою: I дослідній групі внутрішньоочеревно вводили 0,3 \% розчин водорозчинної форми ацетилсаліцилової кислоти (аспірин), з розрахунку 100 мг/кг, один раз на добу, сім діб. Поросятам II групи внутрішньоочеревно вводили препарат «Асглюколу» (спирт, аскорбінова кислота і глюкоза) в дозі 10 мл/кг, один раз на добу, сім діб. Тваринам III групи застосовували «Асглюкол» $\mathrm{i}$ водорозчинний «Аспірин» в тих же дозах, що й I i II групах та вводили внутрішньоочеревенно.

У дослідних тварин відбирали кров 3 очного синуса до початку лікування та на сьому добу i проводили біохімічні дослідження. В сироватці крові визначали активність асапартат- i аланінамінотрансферази за методом РайтманаФренкеля [8, 10].

Статистичну обробку одержаних результатів проводили 3 використанням t-критерію ФішераСтьюдента і стандартного пакета «Статистика» у програмі Microsoft Office Exel 2007.

Результати дослідження. Одержані нами результати стосовно активності трансаміназ сироватки крові поросят у результаті застосування «Аспірину», «Асглюколу» та їх поєднання для лікування гастроентериту наведені в таблиці.

За результатами досліджень у поросят I групи до початку лікування середнє значення активності АсАТ i АлАТ становило 14,3 $\pm 1,20$ i $19,7 \pm 3,10$ Од/л відповідно та не перевищувало верхню межу фізіологічних коливань. На сьому добу досліджень активність трансаміназ сироватки крові тварин не змінилась, що вказувало на відсутність руйнування клітин печінки внаслідок застосування ацетилсаліцилової кислоти.

Аналізуючи результати дослідження сироватки крові поросят II групи, слід зазначити, що на початку лікування активність аланінамінотрансферази в середньому виходила за верхню межу

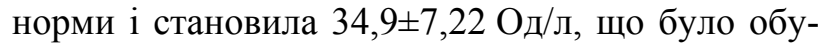
мовлене запальною реакцією слизової оболонки кишківника. Водночас активність АсAТ знаходилась у межах фізіологічних коливань (20,6 $\pm 2,78$ Од/л). На сьому добу лікування у хворих тварин II групи відмічалось підвищення активності вищезазначених ферментів. Показники активності АсАТ і АлАТ зросли у 4,6 та 2,9 рази $(\mathrm{p}<0,001)$ і становили відповідно 93,9 $\pm 8,64$ i

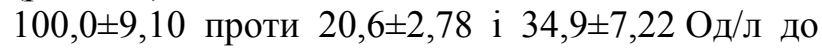
лікування. Значне підвищення активності амінотрансфераз було пов'язане з порушеннями процесів обміну речовин у печінці внаслідок цитолізу гепатоцитів. Адже етиловий спирт, який входить до складу препарату «Асглюкол», окрім позитивної дії (джерело калорій), проявляє негативний вплив, а саме деструкцію мембран гепатоцитів і мітохондрій. Водночас активує перекисне окиснення ліпідів (ПОЛ), а утворений ацетальдегід призводить до руйнування плазматичних мембран шляхом деполімеризації білків.

Результати дослідження сироватки крові поросят III групи на сьому добу лікування зазнали таких змін: активність АсАТ у 20 \% хворих тварин виходила за верхню межу фізіологічних ко-

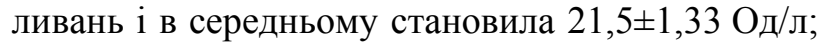
активність АлАТ, навпаки, мала тенденцію до зниження на $26 \%$ та відповідала показнику $30,4 \pm 3,24$ проти 41,1 44,52 Од/л до лікування. Тобто поєднане застосування водорозчинного «Аспірину» 3 «Асглюколом» поросятам третьої групи 3 лікувальною метою не викликало значного цитолізу гепатоцитів, що було, ймовірно, пов'язане 3 дією ацетилсаліцилової кислоти, як протизапального засобу, який зменшує проникність капілярів та проявляє антиоксидантну дію (стимулює синтез ферритину, що зв’язує вільні радикали $(\mathrm{R}+)$ заліза в крові).

За даними літератури [3], коефіцієнт Де Рітіса використовують для діагностики захворювань печінки. В результаті дослідження у поросят трьох груп до лікування і на сьому добу вірогідних змін цього показника виявлено не було. 
ВЕТЕРИНАРНА МЕДИЦИНА

Активність трансаміназ сироватки крові поросят

\begin{tabular}{|c|c|c|c|c|c|c|}
\hline \multirow{2}{*}{ Показник } & \multicolumn{2}{|c|}{ І дослідна, $\mathrm{n}=7$} & \multicolumn{2}{|c|}{ II дослідна, $\mathrm{n}=7$} & \multicolumn{2}{|c|}{ III дослідна, $\mathrm{n}=7$} \\
\cline { 2 - 7 } & до лікування & на 7-му добу & до лікування & на 7-му добу & до лікування & на 7-му добу \\
\hline АсАТ, Од/л & $14,3 \pm 1,21$ & $13,4 \pm 0,93$ & $20,6 \pm 2,78$ & $93,9 \pm 8,64 * * *$ & $17,9 \pm 2,10$ & $21,5 \pm 1,33$ \\
\hline АлАТ, Од/л & $19,7 \pm 3,10$ & $19,8 \pm 2,26$ & $34,9 \pm 7,22$ & $100,0 \pm 9,13 * * *$ & $41,1 \pm 4,52$ & $30,4 \pm 3,24$ \\
\hline $\begin{array}{c}\text { Коефіцієнт } \\
\text { Де Рітіса }\end{array}$ & $0,8 \pm 0,09$ & $0,72 \pm 0,08$ & $0,7 \pm 0,10$ & $1,0 \pm 0,11$ & $0,5 \pm 0,09$ & $0,7 \pm 0,08$ \\
\hline
\end{tabular}

Примітка: ***p $<0,001$ - порівняно 3 показником до введення препарату

Отже, застосування «Аспірину» $з$ лікувальною метою не проявляє гепатотоксичної дії, про що свідчить відсутність вірогідних змін активності амінотрансфераз сироватки крові хворих поро-

\section{БІБЛІОГРАФІЯ}

1. Агапова С. М. Показники крові свиней різних генотипів і їх зв'язок із швидкістю росту / Є. М. Агапова, О. П. Решетніченко // Свинарство: міжвід. темат. наук. збірник. - К. : Аграрна наука, 1996. - №52. - С. 71-77.

2. Бірта Г. О. Гематологічні показники свиней різних генотипів / Г. О. Бірта // Вісник Полтавської державної аграрної академії. - 2011. - №1. C. 77-79.

3. Ветеринарна клінічна біохімія / [Левченко В. І., Влізло В. В., Кондрахін І. П. та ін.] ; за ред. В. І. Левченка і В. Л. Галяса. - Біла Церква, 2002. $400 \mathrm{c}$.

4. До питання одночасного застосування нестероїдних протизапальних препаратів та ацетилсаліцилової кислоти: фармакодинамічна взаємодія, ефективність, підходи до індивідуалізації призначення / [підготовлено редакцією «Українського ревматологічного журналу»] // Український ревматологічний журнал. - К., 2012. - №1 (47). - C. 25-28.

5. Ковач Ю. $Є$. Ефективність свинарства в умовах сьогодення / Ю. С. Ковач // Ефективність використання трудових і матеріальних ресурсів у сучасних умовах у свинарстві / Г. В. Ільїна // Продуктивність агропромислового виробництва (економічні науки) : наук.-практ. збірник Українського науково-дослідного ін-ту. - К. : НДІ Украгропромпродуктивність, 2011. - №19. C. 55-57.

6. Профилактика продукционных нарушений в интенсивном свиноводстве / [Подобед Л. И., Руденко Е. В., Солдатов Е. В. и др.] ; под ред. проф. сят, порівняно 3 «Асглюколом».

Висновок. Застосування водорозчинного «Аспірину» хворим поросятам з лікувальною метою не виявляє гепатотоксичної дії.

Л. И. Подобеда. - Одесса : Печатный дом, 2011. $442 \mathrm{c}$.

7. Співвідношення екологічних, етіологічних і стресових факторів та їх вплив на розвиток біоценотичної патології у тварин / [Береза В. І., Погурський І. Г., Якимчук О. М. та ін.] // В кн. : Конференція проф.-викл. складу і аспір. ННІ вет. медицини, якості і безпеки продукції АПК. - 34 березня 2005 р., НАУ, Київ, Україна. - К. : Вид. центр НАУ, 2005. - С. 12-13.

8. Шатохін П. П. Фармакотерапевтична ефективність перитолу та водорозчинного аспірину у лікуванні поросят, хворих на гастроентерит / П. П. Шатохін, К. В. Супруненко, Л. П. Каришева // Вісник ПДАА. - Полтава : РВВ ПДАА, 2015. №3 (78). - С. 103-108.

9. Шатохін П. П. Фармакотерапевтична ефективність саліцилатів при гастроентеритах : автореф. дис. ... к.вет.н. : спец. 16.00 .04 «Ветеринарна фармакологія з токсикологією» / П. П. Шатохін. - Харків, 1993. - 22 с.

10. Kaneko J. J. Clinical biochemistry of domestic animals 6-th edition / J. J. Kaneko, J. W. Harvey, M. Bruss. - New York : Academmic Press, 2008. - 918 p.

11. Jackson G. G. Peter Clinical examination animals / Peter G. G. Jackson, Peter D. Cockroft. Oxford : Blackwell Science LTD, 2002. - P. 305307.

12. Morag G. Kerr Veterinary laboratory medicine / Kerr G. Morag. - Oxford : Blackwell Science LTD, 2002. - P. 149-152. 